\title{
Elinkeinorakenteen muutoksista Suomessa
}

\author{
KIRSTI WARTIOVAARA
}

Väestöpoliittinen Tutkimuslaitos

Yhteiskunnan muuttumisen - uudenaikaistumisen, teollistumisen tai kaupunkimaistumisen, miltä kannalta sitä milloinkin on katsottu - eräs olennainen osaprosessi on elinkeinorakenteen muutos. Teknillinen ja taloudellinen kehitys tuo mukanaan siirtymisen agraariyhteiskunnasta ensin teollisuus- ja myöhemmin palveluelinkeinovaltaiseen yhteiskuntaan. Tämä kehitys on yhteiskunnan funktionaalista erilaistumista, joka ilmenee työnjaon lisääntymisenä yhteiskunnassa. Työnjaon eriytyessä tehokkuus lisääntyy, mikä on eräs nykyisen yhteiskuntamme päämääristä. Tehokkuuspyrkimys edellyttää myös alueiden keskinäistä erilaistumista. Uudenaikaisten jalostus- ja palveluelinkeinojen lisääntyminen aiheuttaa juuri tällaista työnjaon kehittymistä. Näin pyritään käyttämään kaikkien alueiden taloudellisia voimavaroja mahdollisimman hyvin.

Yhteiskuntasuunnittelu nojautuu yhä enemmän tutkimuksien antamiin viitteisiin. Elinkeinorakennetta koskevat tutkimukset ja ennusteet tulisi olennaisina ottaa huomioon niin, että suunnittelulla pyrittäisiin vaikuttamaan kehitykseen. Tiedot elinkeinorakenteesta ja sen kehityksestä ovat keskeisiä yhteiskunnan toiminnan kannalta, koska elinkeinorakenne liittyy läheisesti yhteiskunnan talouselämään ja sitä kautta vaikuttaa muillakin elämänaloilla.

Tämän tutkielman tarkoituksena on väestötilastojen ja jo tehtyjen ennusteiden avulla valaista elinkeinorakenteen muuttumista Suomessa lähinnä vuoteen 1990 mennessä. Päähuomio on kiinnitetty elinkeinorakenteen ennusteisiin ja alueittaiseen muuttumiseen. Alueellisena yksikkönä on käytetty talousalueita ja seutusuunnittelualueita, koska nämä ovat suunnittelun kannalta mielekkäitä alueita ja koska näistä on ollut tietoja saatavissa. Vertailukohteeksi esitetään lyhyt katsaus eräiden maiden elinkeinorakenteen muutoksiin 1930-luvulta lähtien ja sen jälkeen tarkastellaan lähemmin tähänastista ja tulevaa kehitystä Suomessa.

Koko yhteiskuntamme elinkeinorakenteen muutoksen suunta on selvillä; siitä on viime aikoina laadittu useitakin ennusteita (mm. Helsingin seutukaavaliitto 1967, Mannermaa 1966). Alueittaisia ennusteita elinkeinorakenteen ja työvoiman kehityksestä seuraavien vuosikymmenien aikana on tehty eräissä seutukaavaliitoissa, mutta ne perustuvat vain 
oman alueen tarkasteluun ja niistä puuttuu yhteinen valtakunnallinen kehys, johon ne voitaisiin sijoittaa. Kaikille alueille ei ennustetta ole laadittu ja näin ollen ei ole myöskään voitu laatia elinkeinorakenteen kehityksen tavoitteita. Elinkeinojen sijoitussuunnitelmaa ei maassamme ole eikä liioin sijoittamisen perusteita ole selvitetty.

Elinkeinorakenteen vertailu voidaan tilastoista tehdä joko koko väestön tai vain ammatissa toimivan väestön jakautumista. Suomen ammatissa toimivan väestön elinkeinorakenne on vuosina 1930-1960 muuttunut selvemmin kuin koko väestön elinkeinorakenne. Koko väestön elinkeinorakenteen luokittelussa on vaikeuksia etenkin ammatissa toimimattomien vanhusten ja muiden ammatittomien luokittelun vuoksi, mistä syystä mm. Ruotsissa ei enää vuoden 1960 väestölaskennassa ole esitetty koko väestön elinkeinojakautumaa (ks. esim. Folkräkningen 1960, IX, 2, Arpi 1963, 178). Suunnittelun kannalta tarkoituksenmukaisemman ja luotettavamman kuvan saaneekin ammatissa toimivan väestön elinkeinoa koskevista laskelmista ja ennusteista. Huomattakoon vielä, että elinkeinorakenteen tarkastelussa luokittelun perustana on työpaikka eikä työn laatu kuten ammattiluokittelussa.

\section{Elinkeinorakenteen muutoksen yleinen kulku}

Elinkeinorakenne on eräs yleisesti käytetty taloudellisen kehittyneisyyden osoitin. Yleistäen jalostus- ja palvelutuotannon yhteenlaskettu työvoimaosuus on useimmiten suoraan verrannollinen maan taloudelliseen kehittyneisyyteen (esim. Kiiskinen 1963, 112). Yhteiskunnan kehittyessä elinkeinorakenteessa voidaan erottaa eri vaiheita. Traditionaalisessa yhteiskunnassa suuri osa voimavaroista on ohjattu maatalouteen, jopa 80-90 \% saattaa saada elatuksensa alkutuotannosta (Kiiskinen 1963, 112). Yhteiskunnan taloudellisesti kehittyessä alkutuotannon piirissä työskentelevien osuus vähenee suhteessa jalostuselinkeinoihin, mutta maatalouden tuottavuus kasvaa vaikkakin työvoiman tarve vähenee. Jalostuselinkeinoissa toimivien osuus kohoaa tällöin korkeaksi, mutta vakiintuu myöhemmin tietylle tasolle ja palveluelinkeinojen osuus ylittää sen. Erittäin pitkälle kehittyneessä Iso-Britanniassa jalostuselinkeinoissa toimivien osuus on pientä heilahtelua lukuunottamatta pysynyt samana jo 100 vuoden ajan (Clark 1957, 501). Palveluelinkeinoissa kaupan ja varsinaisten palvelusten osuus kasvaa taloudellisen kehityksen ja väentiheyden kasvun myötä, kun sen sijaan pitkälle mekanisoitavissa oleva liikenne ei välttämättä edellytä jatkuvasti lisääntyvää työvoiman määrää.

Kuvattua kehitystä ovat tarkastelleet teoreettisesti mm. J. Fourastié (1953) ja W. W. Rostow (1962). Fourastién taloudellisen sivilisaatioteorian mukaan työntekijöiden suhteellinen osuus alkutuotannossa, jalostus- ja palveluelinkeinoissa oli noin v. 1800 primaarisen sivilisaation kau- 
della $80 \%-10 \%-10 \%$. Sata vuotta myöhemmin leviämisvaiheessa vastaava jakautuma oli $27 \%-40 \%-33 \%$. Vuoden 2000 vaiheilla on Fourastién mukaan siirrytty tertiaariseen sivilisaatioon, jolloin työntekijöiden osuudet eri elinkeinoissa ovat $10 \%-10 \%-80 \%$. Alkutuotannossa toimivien osuus olisi näin jäänyt pieneksi vähemmistöksi ja teollisuuden työvoiman tarve tulisi olemaan yhtä pieni. Palveluelinkeinojen työvoiman kysyntä sen sijaan nousisi hallitsevaan asemaan. Fourastién mallin mukaan voisi siis kehittyneimpien maidenkin teollisuusja palveluelinkeinojen työvoiman suhde vielä muuttua. Nämä laskelmat eivät tosin osoita minkään maan kehitystä sellaisenaan vaan ne on tehty teollistuneiden maiden tilastojen perusteella. Tulevaisuuden ennuste perustuu siihen, että kehitys noudattaa tähänastista suuntaa.

Rostow on kuvannut viittä taloudellisen kasvun vaihetta. Ensimmäinen on perinteinen yhteiskunta, toisessa vaiheessa luodaan ns. irtaantumisen edellytykset ja kolmas vaihe on irtaantuminen. Tällöin taloudellisesta kasvusta tulee yhteiskunnan pysyvä ja olennainen piirre ja investoinnit nousevat 5-10\%:iin kansantuotteesta. Neljäs vaihe on kypsyminen, jolloin mm. tertiaarielinkeinojen osuus alkaa kasvaa voimakkaasti. Viimein tulee laajan joukkokulutuksen kausi, jolloin taloudellinen kasvu perustuu kestohyödykkeiden valmistukseen ja palveluksiin.

Fourastién teorian mukaan Suomi on tällä hetkellä vaiheessa jolloin jalostus- ja palveluelinkeinojen osuus kasvaa. Toistaiseksi jalostuselinkeinojen osuus kasvusta on ollut vielä aika suuri. Rostowin kuvaamassa kehityskulussa Suomi on ehkä kymmenkunta vuotta sitten siirtynyt laajan joukkokulutuksen kauteen.

\section{Elinkeinorakenteen muutos eräissä maissa vuosina $1930-1960$}

Taulukossa 1 esitetään ammatissa toimivan väestön elinkeinojakautumat Pohjoismaissa ja Yhdysvalloissa kolmen vuosikymmenen ajalta. Taulukon tiedot eivät maiden välisistä sekä eri väestölaskentojen välisistä luokittelueroista johtuen ole täysin vertailukelpoisia, mutta valaisevat kuitenkin kehitystä. Koska tarkoituksena on ollut antaa tiivistetty yleiskuva, elinkeinorakenne on esitetty tässä vain kolmijakona: 1) alkutuotanto, johon kuuluvat maa- ja metsätalous sekä kalastus, 2) jalostuselinkeinot, joissa teollisuus on hallitsevassa asemassa, mutta johon sisältyy myös rakennustoiminta, sähkö-, kaasu- ym. laitokset ja 3) palveluelinkeinot, joihin kuuluvat pankit ja vakuutustoiminta, kauppa, liikenne ja tiedotusvälitys, julkiset palvelukset, henkilölliset ja muut palvelukset.

Sekundaari- ja tertiaarielinkeinojen osuuden kasvu osittain alkutuotannon kustannuksella on havaittavissa kaikkien maiden kohdalla, mutta taloudellisen kehittyneisyyden edetessä muutoksen vauhti vähitellen hiljenee. Vuonna 1960 oli Suomessa elinkeinojakautuma suurin piirtein 
Taulukko 1. Ammatissa toimivan väestön elinkeinorakenne eräissä maissa vuosina 1930-1960 kymmenvuotiskausittain

Table

1. Distribution of the economically active population in the various industries in different countries during 19301960 (in decades)

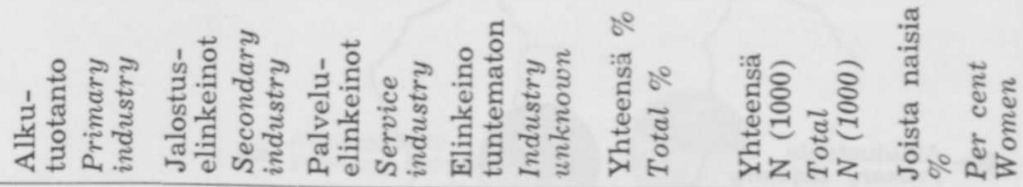

\section{A. Suomi}

1930

1940

1950

1960

B. Ruotsi

Sweden

1930

1940

1950

1960

C. Norja Norway

1930

$1940^{1)}$

1950

1960

D. Tanska

Denmark

1930

1940

1950

1960

E. Yhdysvallat

United States

$\begin{array}{lr}1930 & 22 \\ 1940 & 18 \\ 1950 & 12 \\ 1960 & 6\end{array}$

$\begin{array}{ll}65 & 15 \\ 57 & 19 \\ 46 & 28 \\ 35 & 32\end{array}$

15
19
28
32

13
17
25
33

7
7
1
0

100

1715

2017

1984

100

100

2033

41

43

41

39

$\begin{array}{lllll}31 & 1 & 100 & 2892 & 31 \\ 34 & 1 & 100 & 3000 & 27 \\ 38 & 1 & 100 & 3105 & 26 \\ 41 & 0 & 100 & 3245 & 30\end{array}$

45

32

36

41

14

45

41

38

36

37

44

1168

1376

$\begin{array}{lll}100 & 1376 & - \\ 100 & 1388 & 24\end{array}$

1405

27

$20 \quad 36$

36

36
38
41
44

100

1588

1971

2063

2094

35

100

100

34

31

100

48830

52020

$\begin{array}{ll}100 & 59981 \\ 100 & 69877\end{array}$

$\begin{array}{ll}100 & 59981 \\ 100 & 69877\end{array}$

22
24
27
32

Lähteet: STV 1940, 1948, 1960 ja 1965.

1) Tietoja ei ole saatavissa v. 1940.

Information not available for 1940.

samanlainen kuin muiden Pohjoismaiden vastaavat jakautumat $20-30$ vuotta aikaisemmin ja USA:n noin 50 vuotta aikaisemmin sekä koko väestön että ammatissa toimivan väestön osalta. Elinkeinorakenteen muutos Suomessa saattaa tapahtua nopeammin kuin mainituissa muissa maissa kuten monet muutkin teollistumiseen ja urbanisoitumiseen liittyvät muutokset. Maa- ja metsätaloudessa toimivien osuus kaikista ammatissa toimivista oli maassamme v. 1960 huomattavasti suurempi kuin muissa vertailtavina olevissa maissa. Absoluuttisesti alkutuotannossa toimivien 


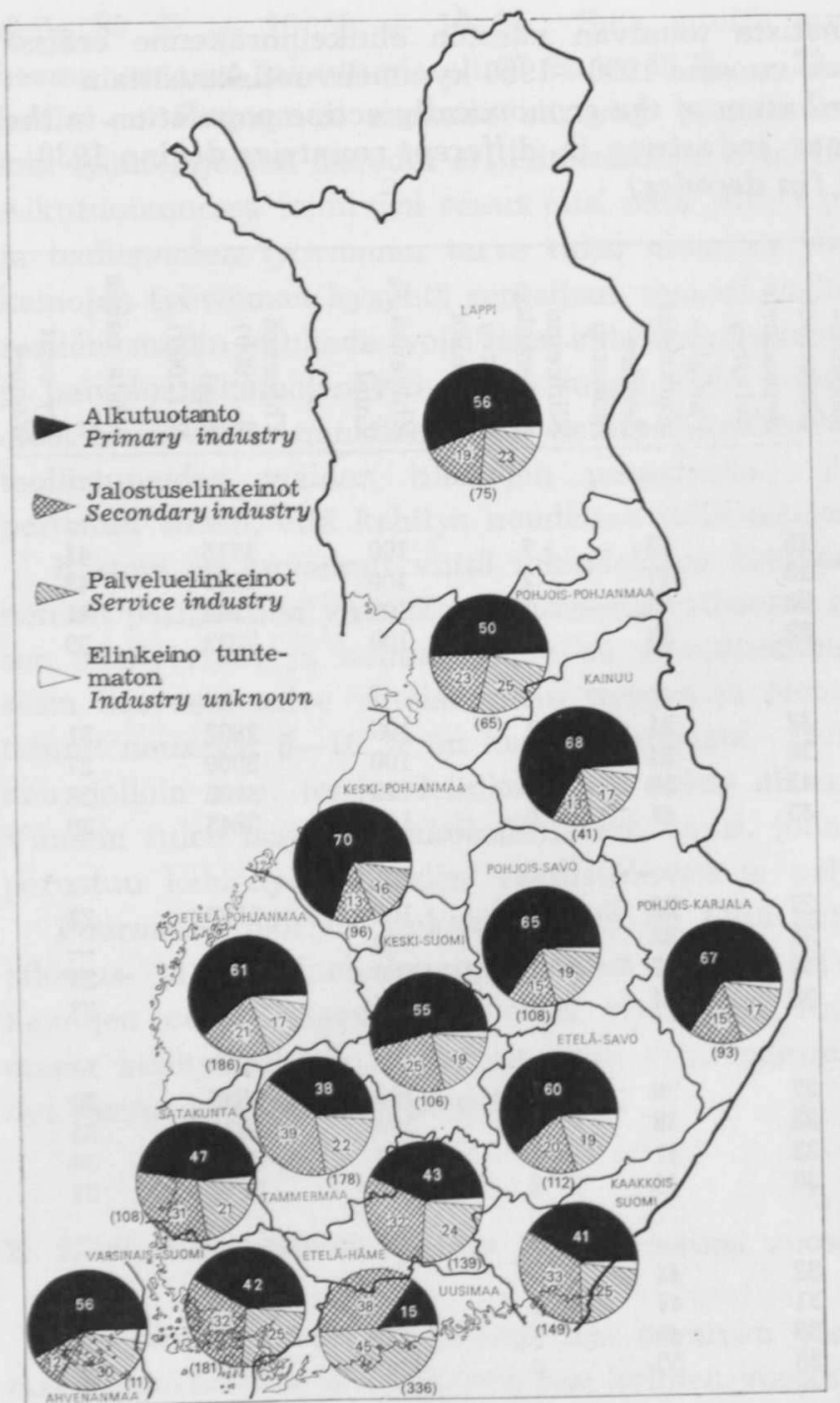

$\mathrm{K}$ u v i o 1. Ammatissa toimivan väestön elinkeinorakenne talousalueittain vuonna 1950 . Figure 1. Economically active population, in the various industries 1950, by statistical regions.

määrä maassamme on vähentynyt vuodesta 1950 vuoteen 1960 noin 200000 hengellä. Suhteellisesti voimakkaimmin ovat kehittyneet kauppa ja teollisuus. Jalostuselinkeinojen osuus on suurin Ruotsissa; palveluselinkeinovaltaisin taas on Yhdysvaltojen elinkeinorakenne, jota lähemmin tarkasteltaessa voidaan todeta etenkin kaupan ja varsinaisten palveluelinkeinojen osuuden olevan selvästi suurempi kuin muissa maissa. Yhdysvalloissa jalostus- ja palveluelinkeinojen osuuksissa on kahden viimeksi suoritetun laskennan välillä tapahtunut vain erittäin vähäisiä muutoksia. Tosin »tuntematon elinkeino» -ryhmään v. 1960 luokitelluista voitaisiin tilastoteknisesti osa siirtää palveluelinkeinoihin kuuluviksi, joten viimeksi mainitun ryhmän osuus voisi yhä vielä kasvaa (Demographic Yearbook 1964, 255). 
$\mathrm{K}$ u v i o 2. Ammatissa toimivan väestön elinkeinorakenne talousalueittain vuonna 1960 . Figure 2. Economically active population, in the various industries 1960 , by statistical regions.

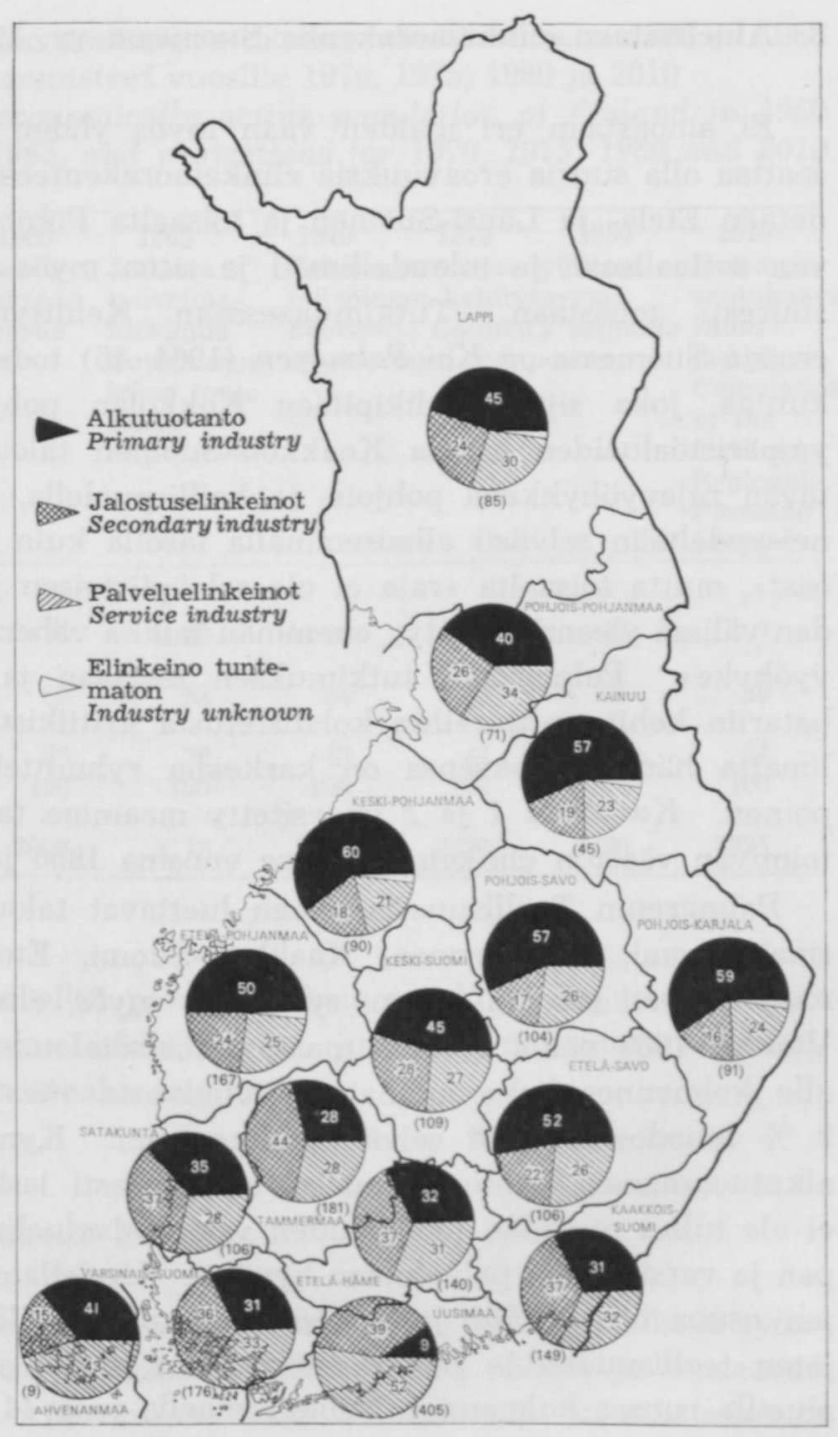

Ammatissa toimivien suhteellinen osuus koko väestöstä on vuodesta 1960 lähtien jatkuvasti laskenut Pohjoismaissa. Tähän lienee syynä ennen kaikkea koulutusajan piteneminen ja vanhusten osuuden kasvu väestöstä. Naisten osuus ammatissa toimivasta väestöstä on taas sekä Ruotsissa että Yhdysvalloissa kasvanut vuodesta 1950 vuoteen 1960, kun muissa maissa lukusarja osoittaa toistaiseksi jatkuvaa laskua. Ruotsissa erityisesti naimisissa olevien naisten osuus ammatissa toimivista on kaikissa ikäluokissa kohonnut, kokonaislisäys on ollut $81 \%$ vuodesta 1950 vuoteen 1960 (Statistisk årsbok 1965, 26), kun koko ammatissa toimivan väestön lisäys on ollut $4.5 \%$. Suomessa tosin on jo niin korkea naisten työhönosallistuvuusprosentti, ettei se ehkä enää voi nousta yhtä lailla kuin Ruotsissa. 


\section{Alueittainen elinkeinorakenne Suomessa vv. $1950-1960$}

Ei ainoastaan eri maiden vaan myös yhden maan eri osien välillä saattaa olla suuria eroavuuksia elinkeinorakenteessa. Varsin yleisesti tiedetään Etelä- ja Länsi-Suomen ja toisaalta Pohjois- ja Itä-Suomen eroavan sosiaalisesti ja taloudellisesti ja siten myös elinkeinorakenteellisesti suuresti toisistaan. Tutkimuksessaan Kehittyneisyyden alueittaisista eroista Suomessa on Kai Palmgren $(1964,46)$ todennut että "se osa valtakuntaa, joka sijaitsee likipitäen Kokkolan pohjoispuolelta Jyväskylän ympäristöalueiden kautta Kaakkois-Suomen talousalueen itäosiin vedettävän rajavyöhykkeen pohjois- ja koillispuolella, näyttää olevan kehittyneisyydeltään selvästi alhaisemmalla tasolla kuin maan etelä- ja lounaisosat», mutta toisaalta »raja ei ole selväpiirteisen jyrkkä, vaan em. alueiden välissä yleensä esiintyy enemmän taikka vähemmän selvä vaihettumisvyöhyke». Palmgrenin tutkimuksen teoriaan ja metodeihin, erityisesti hatariin kehitysmittareihin kohdistetusta kritiikistä (Riihinen 1967) huolimatta hänen tuloksensa on karkeana ryhmittelyperusteena käyttökelpoinen. Kuvioissa 1 ja 2 on esitetty maamme talousalueiden ammatissa toimivan väestön elinkeinorakenne vuosina 1950 ja 1960 .

Palmgrenin Teollisuus-Suomeen luettavat talousalueet Uusimaa, Varsinais-Suomi, Tammermaa, Kaakkois-Suomi, Etelä-Häme ja Satakunta muodostavat selvästi oman ryhmänsä myös elinkeinorakenteen osalta. Vuonna 1960 näillä alueilla maa- ja metsätaloudessa oli yleensä hieman alle kolmannes koko ammatissa toimivasta väestöstä, vain Uudenmaan $9 \%$ muodostaa tästä selvän poikkeuksen. Kymmenen vuoden aikana alkutuotannossa toimivien määrä on nopeasti laskenut. Vastaava lisäys ei ole tullut niinkään teollisuuden vaan palveluelinkeinojen, etenkin kaupan ja varsinaisten palvelusten hyväksi. Uudellamaalla tertiaarielinkeinojen osuus oli v. 1960 jo yli $50 \%$, muilla teollisuusalueilla $28-32 \%$, joten teollisuuden ja rakennustoiminnan yhteenlaskettu osuus oli näillä alueilla runsas kolmannes, Tammermaalla jopa $44 \%$.

Kehittyneisyyden kannalta eräänlaisen välivaiheen alueita ovat KeskiSuomi, Etelä-Pohjanmaa, Pohjois-Pohjanmaa ja Ahvenanmaa. Yli $40 \%$ ammatissa toimivasta väestöstä oli primaarielinkeinojen piirissä, vaikkakin työvoimaa siirtyy muihin elinkeinoihin. Etenkin Ahvenanmaalla suhteellinen väheneminen on ollut huomattava ja lisäys näkyy palvelusten, erikoista kyllä myös liikenteen, kohdalla. Teollisuusväestön osuus näillä alueilla ei ole kasvanut juuri lainkaan, rakennustoiminnan erittäin vähän.

Alhaisinta kehittyneisyyttä edustavat Kainuu, Keski-Pohjanmaa, Lappi, Etelä-Savo, Pohjois-Karjala ja Pohjois-Savo. Nämä ovat yhä maatalousvaltaisia alueita. Maa- ja metsätaloudessa työskentelevien siirtyminen muihin elinkeinoryhmiin on täällä hitaampaa kuin muualla maassa. Rakennustoimintaan on voitu sijoittaa jonkin verran maatalouden liikaväestöä, 
T a u lukko 2. Suomen ammatissa toimiva väestö vuosina 1960 ja 1965 sekä ennusteet vuosille 1970, 1975, 1980 ja 2010

Table 2. The economically active population of Finland in 1960 and 1965, and projections for 1970, 1975, 1980 and 2010

\begin{tabular}{|c|c|c|c|c|c|c|}
\hline & $\begin{array}{c}1960 \\
\text { Väestö- } \\
\text { laskenta } \\
\text { Census }\end{array}$ & $\begin{array}{l}\quad 1965 \\
\text { Jatkuva } \\
\text { työvoima- } \\
\text { tutkimus } \\
\text { Continuous } \\
\text { labor force } \\
\text { study }\end{array}$ & $\begin{array}{l}1970 \\
\text { Talous } \\
\text { työvoir } \\
\text { Econor } \\
\text { of emp }\end{array}$ & $\begin{array}{l}1975 \\
\text { uvoston } \\
\text { n kehity } \\
\text { c Counci } \\
\text { yed man }\end{array}$ & $\begin{array}{l}1980 \\
\text { työllisen } \\
\text { ysarviot } \\
\text { il's estimate } \\
\text { npower }\end{array}$ & $\begin{array}{l}\quad 2010 \\
\text { Helsingin } \\
\text { seutukaav } \\
\text { liiton } \\
\text { laskelma } \\
\text { Calculation } \\
\text { of the } \\
\text { Helsinki } \\
\text { Regional } \\
\text { Planning } \\
\text { League }\end{array}$ \\
\hline \multicolumn{7}{|l|}{ Maa- ja metsätalous - } \\
\hline $\begin{array}{l}\text { Agriculture and forestry } \\
\text { Jalostuselinkeinot - }\end{array}$ & 35 & 30 & 26 & 21 & 15 & 7 \\
\hline $\begin{array}{l}\text { Secondary industries . . } \\
\text { Palveluelinkeinot - }\end{array}$ & 32 & 32 & 34 & 35 & 36 & 39 \\
\hline Service industries & 33 & 38 & 40 & 44 & 49 & 54 \\
\hline $\begin{array}{l}\text { Yhteensä \% - Total \% } \\
\text { N (1000 henkeä) - }\end{array}$ & 100 & 100 & 100 & 100 & 100 & 100 \\
\hline$N$ (1000 persons) ...... & . . 2033 & 2172 & 2260 & 2320 & 3480 & 2295 \\
\hline
\end{tabular}

mutta suurinta kasvu on ollut palveluelinkeinojen kohdalla, joiden osuus on yllättävän korkea mm. lakisääteisten julkisten palvelusten vuoksi. Myös kaupan piirissä on tapahtunut kasvua.

\section{Elinkeinoelämän ennakoitu kehitys}

Elinkeinoelämän rakennemuutoksena ilmenevä yhteiskunnallisen työnjaon lisääntyminen jatkuu maassamme oletettavasti tämän ja seuraavan vuosikymmenen aikana. Ennusteita tästä kehityksestä on aikaisemmin esitetty mm. Talousneuvoston mietinnössä vuoteen 1967 (1964) ja Työvoimatutkimustoimiston ennusteessa vuoteen 1975 (Työvoimakatsaus 1, 1965). Uusimmat ennusteista lienevät Talousneuvoston sihteeristön julkaisema, Kauko Mannermaan laatima Arvio työvoiman kysynnän ja tarjonnan kehityksestä vuosina 1965-1980 (1966) ja Helsingin seutukaavaliiton julkaisema ns. Vuorensyrjän ennuste Elinkeinot vuosina 19652010 (1967). Taulukossa 2 on esitetty elinkeinohaaroittain prosenttilukuina vuoden 1960 väestölaskennassa ammatissa toimiva väestö, työvoimatutkimustoimiston arviolukuihin perustuvan jatkuvan työvoimatutkimuksen tulokset vuodelta 1965 (Työvoimakatsaus 1966) ja uusien arvioiden ja ennusteiden tulokset.

Vuonna 1960 oli vielä suhteellisesti eniten työvoimaa alkutuotannon piirissä, mutta jo vuonna 1965 tämä luku oli pienin ja palveluelinkeino- 
Taulukko 3. Ruotsin ammatissa toimivan väestön ennusteet vuosille 1970 ja 1980

T $a b l e \quad 3$. The projected economically active population in Sweden for 1970 and 1980

\begin{tabular}{|c|c|c|}
\hline & 1970 & 1980 \\
\hline Alkutuotanto - Primary industries & 7 & 3 \\
\hline Jalostuselinkeinot - Secondary industries & 45 & 43 \\
\hline Palveluelinkeinot - Service industries & 48 & 54 \\
\hline Yhteensä $\%$ - Total $\%$................ & 100 & 100 \\
\hline$N$ (tuhansia) $-N($ in 1000$)$ & 3510 & 3700 \\
\hline
\end{tabular}

Lähde: Svensk ekonomi 1966-1970, 1966, 122 ja 250

jen osuus suurin. Kehityssuunta on aivan selvä: alkutuotantoa edustavista elinkeinoista siirtyy runsaasti työvoimaa muille aloille, palveluelinkeinojen merkitys työvoiman kysyjänä kasvaa erittäin voimakkaasti kun taas teollisuuden työvoiman kysyntä kasvaa hitaasti. Vuonna 2010 alkutuotanto työllistäisi Vuorensyrjän mukaan vain $7 \%$ työvoimasta. Teollisuuden työvoiman kasvu tapahtuu pääasiassa 1960- ja 1970-luvun aikana. Palveluelinkeinojen työvoima kasvaa sen sijaan myös ennustekauden lopulla.

Ennustuksiin liittyy paljon epävarmuutta, koska kaikkia kehitykseen vaikuttavia tekijöitä ei tunneta riittävän tarkasti. Sitä ilmentävät myös taulukossa 2 esitettyjen ennusteiden toisistaan poikkeavat lopputulokset lähinnä koko työvoiman määrän ja jalostuselinkeinojen kehittymisen osalta. Näiden ennusteiden eroa aiheuttaa lähinnä erilainen taloudellisten kasvumahdollisuuksien arviointi. Elinkeinorakenteen muutokset ovat läheisesti yhteydessä taloudelliseen kasvuun ja viime kädessä myös muiden maiden taloudelliseen kasvuun. Sekä Mannermaan että Vuorensyrjän ennusteessa on lähtökohtana ollut bruttokansantuotteen kasvun arviointi. Mannermaa olettaa kasvun olevan jatkuvasti $4 \%$, $4.5 \%$ tai $5 \%$ vuodessa ja esittää kolme vaihtoehtoista laskelmaa näiden perusteella. $5 \%$ :n kasvu edellyttäisi vuosina 1955-1965 todetun kasvunopeuden säilymistä. Kahden muun vaihtoehdon valinnassa on otettu huomioon kansainvälisen kilpailun kiristyminen, raaka-ainevarojemme riittävyys ja työpanoksen kasvun hidastuminen. Vuorensyrjä puolestaan olettaa, että kansantuotteen keskimääräinen kasvuvauhti ei jaksa pysytellä nykyisellä tasollaan, vaan vuosittain kokonaiskasvu laskee nykyisestä $5 \%$ :sta $3.3 \%$ :iin v. 2010. Tämä perusteena Vuorensyrjä toteaa, että bruttokansantuotteen kasvunopeus on jo taantunut 1960-luvun alkupuolen aikana. Lisäksi hän esittää vertailuaineistoa maista, joissa on maatamme aikaisemmin saavutettu laajan joukkokulutuksen kausi.

Molemmissa ennusteissa on huomioitu erikseen t yö v o i m a n kysyntä ja tarjonta sekä niiden sopeutuminen toisiinsa. Mannermaa on laskenut jalostus- ja palveluelinkeinojen tuotannon volyymin kasvun olettaen, 
että tulevaisuudessa vallitsee aikaisemmin todettu yhteys ao. elinkeinon tuotannon volyymin ja kansantuotteen volyymin välillä. Alkutuotannon volyymin kasvunopeuden on oletettu olevan keskimäärin runsaat $1.5 \%$ vuodessa. Työpanoksen eli työhön käytettyjen aikayksiköiden määrän kasvu on arvioitu käyttämällä hyväksi työpanoksen, tuotannon ja aikatekijällä mitatun tuottavuuden välillä havaittuja riippuvuussuhteita. Työpanoksena mitatut arviot on sitten muutettu henkilömääriksi olettamalla että työpanoksen ja työllisen työvoiman suhde eri elinkeinoryhmissä säilyy samana kuin vuonna 1965 lukuunottamatta työajan lyhenemisen vaikutusta. Laskelmien mukaan työvoiman kysyntä tulevaisuudessa kasvaisi $2.1-2.7 \%$ vuodessa.

Vuorensyrjä on laskenut työvoiman kysynnän käyttäen tuotantofunktiota tuotanto $=$ työvoima $\times$ työaika $\times$ tuottavuus. Ensin hän on ennustanut itsenäisesti bruttokansantuotteen ja tuottavuuden (bruttokansantuote/työvuosi) kehityksen elinkeinoittain tapahtuneen kehityksen ja ulkomaisten vertailulukujen perusteella. Työajan muutokset on myös ennustettu itsenäisesti. Näiden ennusteiden avulla on laskettu tulevaisuudessa tarvittava työpanoksen määrä ja työpanosluvut on muutettu työvoimaksi. Ilmiöiden keskinäisen riippuvuuden vuoksi käytännössä työvoima, tuotanto ja tuottavuus laskettiin vuoron perään kahden muun tekijän ja työajasta tehtyjen olettamusten ja työvoiman tarjonnan ilmaisemien rajoitusten avulla. Saatujen tulosten käyttökelpoisuuden kriteereinä toimivat ko. ilmiöiden viimeaikaiset kehitystrendit, ilmiöiden keskinäiset suhteet ja ulkomaiset vertailuluvut.

Koska työvoiman kysynnän on sopeuduttava tarjontaan, on molemmissa ennusteissa tarkasteltu erikseen myös työvoiman tarjontaa. Mannermaa on käyttänyt Työvoimatutkimustoimiston laatimia ennusteita, jotka on laadittu periaatteessa samoin kuin Vuorensyrjänkin ennusteen tarjonnan kehitys. Ikäluokittaisen väestöennusteen perusteella on laskettu työvoimaosuudet eli työvoiman prosentuaaliset osuudet työikäisestä väestöstä.

Mannermaan arviossa maatalouden työvoiman vähenemisnopeus olisi tämän vuosikymmenen lopussa $5-7 \%$ vuodessa. Arvio on saatu maatalouden osalta jäännöslukuna muiden elinkeinojen kasvun arvioinnin jälkeen. Jos arvio pitäisi paikkansa olisi alkutuotannossa toimivan työvoiman osuus Suomessa vielä vuonna 1980 vähän suurempi kuin se oli Ruotsissa vuonna 1960 (vrt. taul. 1). Maatalouden työvoiman vähenemisnopeus riippuu kuitenkin olennaisesti muun elinkeinoelämän työvoiman kysynnästä ja myös siis kokonaistuotannon kasvusta. Toisaalta saattavat Mannermaan mukaan »koulutuksen riittämättömyys, asunto-ongelmat, asennekysymykset ym. seikat, jotka ovat esteenä turvalliselle siirtymiselle maatalousammateista teollisuus- ja palveluammatteihin jarruttaa mukautumisprosessia” (1966, 19-20).

Työvoiman kasvu tulee ennusteiden mukaan vuodesta 1965 lähtien 
hidastumaan. Tämä ilmiö on havaittavissa myös muissa maissa. Tähän vaikuttaa oleellisesti väestön kasvun hidastuminen. Työvoimaosuuksissa tapahtuviin muutoksiin vaikuttavat eniten koulutusajan piteneminen, muutokset yli 60 -vuotiaiden ikäluokkien ja naimisissa olevien naisten työhön osallistumisessa.

Ruotsissa tulee työvoiman kasvun hidastuminen olemaan suunnilleen yhtä suuri kuin meilläkin. Erään ennusteen mukaan kasvu on $0.7 \%$ vuosina 1966-1970 oltuaan $1.0 \%$ tätä edeltäneenä viisivuotiskautena (Svensk ekonomi 1966-1970, 1966, 33). Eri elinkeinoissa tapahtuvat vuosittaiset muutokset on Ruotsissa ennustettu seuraaviksi vuosina 19651970: alkutuotanto $-5.5 \%$, jalostuselinkeinot $+1.0 \%$ ja palveluelinkeinot $+1.5 \%$ (m.t. 121). Ammatissa toimivan väestön jakautumisen eri elinkeinoihin ennustetaan vuosina 1970 ja 1980 olevan Ruotsissa seuraava:

Ruotsin teollisuuden käyttämä työvoima on nyt vakiintumassa niin että sen osuus olisi hieman alle puolet koko ammatissa toimivasta väestöstä. Vuosina 1960 ja 1970 teollisuudessa toimisi suunnilleen yhtä suuri osuus työvoimasta ja sen jälkeen osuuden arvioidaan hieman laskevan. Palveluelinkeinot saavat tällöin työllistää maataloudesta vielä vapautuvan väestön. Palveluelinkeinojen osuus nousisi jo ensi vuosikymmenellä melkein puoleen ammatissa toimivasta väestöstä.

\section{Alueittaiset väestöennusteet Suomessa}

Vuoden 1960 väestölaskennan ja sitä seuraavien vuosien väestökehityksen perusteella on maassamme tehty kolme koko maata käsittävää alueellista väestönkehityslaskelmaa: Tilastollisen päätoimiston talousalueittainen väestö- ja ruokakuntaennuste vuoteen 1990 (1964), Valtakunnansuunnittelutoimiston kunnittainen laskelma väestönkehityksestä ilman muuttoliikkeen vaikutusta vuosina 1960 -1990 ja sama laskelma muuttoliike huomioon otettuna (1964). Nämä laskelmat on tehty lähtien vain demografisista syntyvyyttä, kuolevuutta ja muuttoliikettä koskevista tiedoista. Tällaisten demografisin perustein laadittujen laskelmien heikkoutena on ennen kaikkea se, että muuttoliikkeen kehitysarviot joudutaan tekemään pelkästään aikaisemman kehityksen perusteella. Kuitenkin muuttoliikkeen laajuus muuttuu jatkuvasti, joten laskelmat pitäisi esimerkiksi viisivuotiskausittain tarkistaa.

Seutukaavaliittojen laskelmissa on yleensä pyritty arvioimaan eri elinkeinoryhmien ammatissa toimivan väestön oletettavissa oleva kehitys vuosina 1960-1990. Sen perusteella on laskettu työikäisen väestön kehitysarvio. Tätä on verrattu edellä esitettyjen Valtakunnansuunnittelutoimiston molempien laskelmien tuloksiin. Vertailun perusteella on laadittu laskelma kokonaisväestömääristä. Täten on siis välillisesti arvioitu muuttoliikkeen oletettu kehitys työikäisen väestön osalta.

Seutukaavaliittojen teettämät laskelmat on tehty lähinnä fyysisen suunnittelun avuksi. On tarvittu tietoja ja jonkinlaisia opasteita seutu- 
kaava-alueiden suunnittelussa. Ennusteet perustuvat olettamuksille, joiden ei edes odoteta pitävän kovinkaan tarkkaan paikkaansa ja käytetyt ennustemenetelmät ovat yksinkertaisia. Käyttötarkoituksen vuoksi ennustettava ajanjakso on pitkä ja täten myös virhemahdollisuus kasvaa. Näin ollen saatujen lukujen ei myöskään odoteta toteutuvan täsmälleen; pikemminkin ne osoittavat kehityksen kulun, jos tähänastisen kehityksen perusteella tehdyt lähtökohtaolettamukset pitävät paikkansa. Laskelmat eivät myöskään ole tavoitteita tai suunnitteita siinä mielessä, että kehityksen haluttaisiin ennustetusti tapahtuvan, vaan arvioita nyt nähtävissä olevan kehityksen jatkumisesta jos siihen ei enemmälti puututa.

Seutukaavaliittojen toimeksiannosta on Suomessa tehty seuraavat väestöennusteet, joihin sisältyvät työvoiman elinkeinohaaroittaiset kehitysennusteet: Etelä-Pohjanmaan väestöennuste 1960-1990 (1964-1965), Befolkningen i Vasa läns kustområde 1960-1990 (1964, 1965), KantaHämeen väestöennuste 1960 -1990 seutukunnittain (1966), Salon seutukaava-alueen väestöennuste $1960-1990$ (1966) ja Tampereen talousalueen väestöennuste $1960-1990$ (1966). Lisäksi on saatu käytettäväksi julkaisematon aineisto Laskelmia Satakunnan väestökehityksestä 1960_ 1990, elinkeinojakautumaa koskevat tiedot Kymenlaakson valmisteilla olevasta väestöennusteesta ja laskelma Helsingin lähivaikutusalueen työpaikoista $1965-2000 .^{1}$

Puuttumatta yksityiskohtaisesti ennusteiden laskuperusteisiin voidaan ennusteissa erottaa yhteisiä laatimistapoja.

Yleensä ennusteissa on todettu maa- ja metsätalousväestön väheneminen oleellisimmaksi elinkeinorakennetta muuttavaksi tekijäksi ja tämän ryhmän arviointeihin on kiinnitetty eniten huomiota. Toisaalta maaja metsätalousväestön kehitystä on vaikea laskea, koska se riippuu siitä, miten muut elinkeinot voivat ottaa vastaan maataloudesta vapautuvan työvoiman. Maataloudessa työskentelevän työvoiman määrän kehitykseen vaikuttavat lähinnä seuraavat tekijät (Suomela 1966, 63-64): rationalisointi (koneiden käyttö, työmenetelmien kehittyminen, viljelytekniikan muuttuminen jne), maatalouden tuotantosuunta, pelto- ja metsäpintaalat, tilakoko ja kehitys muilla aloilla. Peltopinta-alan kasvu merkitsee maatalouden laajenemista ja sitä tietä työvoiman käytön lisääntymistä. Toisaalta tilan koon kasvaminen voi tuntuvasti vähentää maatilataloudessa tarvittavan työvoiman määrää, sillä pienillä tiloilla voi hehtaaria kohti tarvittava työmäärä olla jopa kaksin-kolminkertainen verrattuna suurten tilojen työmenekkiin. Kuten jo edellä mainittiin, maatalouden työvoiman tarpeeseen vaikuttaa ratkaisevasti vielä muiden alojen kehittyminen ja ansiomahdollisuudet maatalouden ulkopuolella.

1 Helsingin lähivaikutusalue käsittää Helsingin, Espoon, Helsingin maalaiskunnan, Kirkkonummen, Vihdin, Nurmijärven, Tuusulan, Järvenpään, Keravan, Kauniaisen ja Sipoon. 
Maa-ja metsätalousväestön kehitys on arvioissa laskettu useammalla eri tavalla. Etelä-Pohjanmaan, Vaasan, Kanta-Hämeen, Salon ja Tampereen ennusteissa on ammatissa toimivan väestön kehitys laskettu työmenekin mukaan. Tällöin on huomioitu peltohehtaaria kohden tarvittavan työmäärän muutosten ja viljelmien keskisuuruuden vaikutus työmenekkiin ja laskettu ammatissa toimivan väestön suhde työmenekkiin. Väestön lukumäärän kehityksen perusteella on tehty toinen arvio neljässä ensin mainitussa ennusteessa. Näissä on vertailtu ammatissa toimivien määrän kehitystä 100 peltohehtaaria kohden viime vuosikymmenien aikana maamme eri alueilla. Lisäksi on arvioitu peltopintaalassa tapahtuvat muutokset ja laadittu tämän perusteella ennuste ammatissa toimivalle väestölle.

T e ollis u udess a toimivan väestön ennustetta laadittaessa on turvauduttu aikaisempiin tutkimuksiin, kehitykseen 1950-luvulla sekä teollisuustilaston tietoihin. Kanta-Hämeessä on lisäksi tehty haastatteluselvitys työvoiman todennäköisestä kehityksestä nykyisissä yli 20 henkilön teollisuusyrityksissä vuoteen 1970 mennessä. Koska teollisuustilastosta puuttuu käsi- ja pienteollisuuden henkilökuntaa, on kehityksen perusteella saatuihin ennusteisiin lisätty väestölaskennan ja teollisuustilaston välisen erotuksen arvio.

Rakennustoiminta riippuu luonnollisesti fyysisestä suunnittelusta ja teollisuuden kasvusta. Ennusteen laatimisessa on käytetty hyväksi 1950-luvun kehitystä ja joissakin ennusteissa kehitys on sidottu teollisuuden kasvuun siten että rakennustoiminnassa toimii $10 \%$ teollisuuden väestön määrästä.

Myös palveluelinkein oiss a toimivien määrä on riippuvainen mm. teollisuuden kehityksestä, tuottavuudesta, väestön määrästä ja seudun erikoispiirteistä. 1950-luvun kehityksen ja eri alueiden kehityksen vertailun perusteella on palveluelinkeinoissa toimivan väestön ennuste laskettu.

Toistaiseksi julkaisematon Satakunnan väestöennuste on laskettu muista poikkeavasti. Väestön kehitystä on tarkasteltu taloudellisen kasvun indikaattorina tässä ennusteessa. Elinkeinot on jaettu primaari- ja sekundaarielinkeinoihin. Ensin mainittuihin on sisällytetty maa- ja metsätalous, teollisuus ja käsityö ja viimeksi mainittuihin rakennustoiminta, palvelukset ja luokittelematon toiminta. Laskelma perustuu siihen, että ammatissa toimivan väestön osuus sekundaarielinkeinoissa on tietyssä suhteessa koko alueella toimivaan väestöön. Kun ammatissa toimiva väestö primaarielinkeinoissa on arvioitu voidaan laskea myös sekundaarielinkeinojen ennuste. Maa- ja metsätalousväestön ennusteessa on perusteena käytetty työpanoksen muutosta ja peltoalan mahdollisia muutoksia. Teollisuuden työvoimatarve on ennustettu aikaisemman kehityksen perusteella. Sekundaarielinkeinojen ennuste on tehty aikaisemman kehityksen sekä Ruotsissa todetun ja ennustetun kehityksen perusteella. 
Taulukossa 4 on esitetty käytettävänä olleiden seutukaavaliittojen ammatissa toimivan väestön kehitys. Eri ennusteissa esitetyistä vaihtoehdoista on taulukkoon otettu vain yksi.

Maamme eri alueilla elinkeinorakenne on jo selvästi erilainen. Tulevaisuudessa tämä yhteiskunnallinen työjako yhä lisääntyy. Tarkastelluista alueista Salon ja Etelä-Pohjanmaan alue tulevat säilyttämään eniten työvoimaa maa- ja metsätalouden piirissä. Tammermaa ja KantaHäme tulevat olemaan voimakkaasti teollistuneita alueita. Palveluselinkeinovaltaisin on ylivoimaisesti Helsingin seutu $\mathrm{mm}$. hallinnollisena ja kulttuurikeskuksena. Myös Satakunnassa ja Kymenlaaksossa on ennusteiden mukaan jo nähtävissä aika, jolloin palveluelinkeinoissa toimii yli puolet ammatissa toimivasta väestöstä. Tässä kehityksessä alueet ovat luonnollisesti toisistaan riippuvaisia, mitä näitä ennusteita laadittaessa ei ole voitu ottaa huomioon.

Salon seutu muodostuu maaperän ja sijainnin sopivuuden vuoksi voimakkaasti maa- ja metsätalousalueeksi. Alueen ammatissa toimivasta väestöstä toimi vuonna 1960 noin puolet maa- ja metsätalouden piirissä ja neljäsosa teollisuudessa ja neljäsosa palveluelinkeinoissa. Maa- ja metsätalousväestön on oletettu vähenevän 2.0 , 1.5 ja 1.0 prosenttia vuodessa kymmenvuotiskausittain ja peltoalan osalta matalouden on laskettu säilyvän likimain nykyisessä laajuudessa. Vuonna 1990 ennustetaan vielä runsaan neljänneksen toimivan maa- ja metsätalouden piirissä, noin kolmanneksen teollisuudessa ja rakennustoiminnassa ja hieman enemmän työväestöä palveluelinkeinoissa. Koko alueen ammatissa toimivan väestön määrän on laskettu pienenevän vain muutamalla sadalla hengellä.

Etelä-Pohjanmaan ammatissa toimivan väestön jakautuma oli vuonna 1960 sama kuin Salon alueenkin, ja ennusteen mukaan tulee kehitys olemaan suunnilleen samanlainen molemmilla alueilla. Koko Etelä-Pohjanmaan alueella ammatissa toimiva väestö vähenee ennusteen mukaan vuoteen 1980, jolloin tapahtuu käänne nousuun päin. Tosin muutokset ovat pieniä, kokonaismäärässä tapahtuu vain noin $4 \%$ :n vähentyminen. Maaja metsätaloudessa toimivien määrä tulee laskemaan lähes 40000 hengellä, lisäys teollisuudessa ja rakennustoiminnassa on noin 13000 ja palveluelinkeinoissa noin 20000 henkeä.

Tammermaan ja Kanta-Hämeen elinkeinorakenteet tulisivat ennusteiden mukaan säilymään teollisuusvaltaisina vuonna 1990. Näillä alueilla myös ammatissa toimivien kokonaismäärä osoittaa jatkuvaa kasvua. Tammermaalla ammatissa toimiva väestö kasvaa ennusteen mukaan vuodesta 1960 vuoteen 1990 mennessä noin $11.5 \%$ eli 21200 henkeä. Maa- ja metsätaloudessa toimiva väestö vähenee noin 24000 hengellä. Teollisuusväestön lisäys on 16500 ja palveluelinkeinoissa toimivien 29000 henkeä.

Kanta-Hämeen ammatissa toimiva väestö kasvaa noin 2000 henkilöllä vuoteen 1990. Maa- ja metsätalousväestö vähenee noin puoleen nykyisestään. Teollisuusväestön osuus tulee nousemaan noin 44 ja palvelu- 
Ta ulukko 4. Eräiden seutukaava-alueiden ennustettu ammatissa toimivan väestön kehitys vuosina $1960-1990$

Table 4. Projected developments in the economically active population during 1960-1990 in different regional planning areas

\begin{tabular}{lccccccc} 
& $\mathrm{N}(1000)$ & & \multicolumn{3}{c}{$\%$} \\
1960 & 1970 & 1980 & 1990 & 1960 & 1970 & 1980 & 1990
\end{tabular}

\section{Etelä-Pohjanmaan tilastoalue}

Southern Ostrobothnia statistical region

Maa- ja metsätal. sivuelinkeinoineen - Agriculture, forestry and related

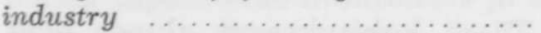
Teollisuus ja rakennustoiminta Industry and construction .......... Palveluelinkeinot - Service industries Elinkeino tuntematon -

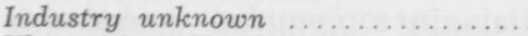

Yhteensä - Total

Vaasan rannikkoalue

Vaasa coastal region

Maa- ja metsätal. sivuelinkeinoineen - Agriculture, forestry, and related industry ....................... Teollisuus ja rakennustoiminta Industry and construction ........... Palveluelinkeinot - Service industries Elinkeino tuntematon -

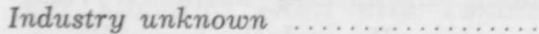

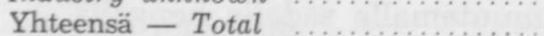

\section{Kanta-Häme}

Kanta-Häme

Maa- ja metsätal. sivuelinkeinoineen - Agriculture, forestry, and related industry

Teollisuus ja rakennustoiminta Industry and construction ...........

Palveluelinkeinot - Service industries Elinkeino tuntematon -

Industry unknown

Yhteensä - Total

$\begin{array}{rrrrrrrr}84.3 & 69.8 & 56.5 & 45.7 & 50 & 43 & 35 & 28 \\ & & & & & & & \\ 40.9 & 44.0 & 48.8 & 54.2 & 25 & 27 & 31 & 34 \\ 41.1 & 48.7 & 54.4 & 61.1 & 25 & 30 & 34 & 38 \\ & & & & & & & \\ 0.9 & 0.5 & 0.5 & 0.5 & 0 & 0 & 0 & 0 \\ 167.3 & 163.0 & 160.2 & 161.5 & 100 & 100 & 100 & 100\end{array}$

$\begin{array}{rrrrrrrr}23.6 & 19.4 & 15.0 & 11.5 & 35 & 28 & 21 & 17 \\ 23.1 & 25.5 & 28.6 & 30.9 & 34 & 37 & 41 & 44 \\ 20.5 & 24.4 & 26.4 & 27.5 & 31 & 35 & 38 & 39 \\ & & & & & & & \\ 0.3 & 0.2 & 0.2 & 0.2 & 0 & 0 & 0 & 0 \\ 69.5 & 69.5 & 70.2 & 70.1 & 100 & 100 & 100 & 100\end{array}$

Salon seutukaava-alue

Salo regional planning area

Maa- ja metsätal. sivuelinkeinoineen - Agriculture, forestry, and related industry ........................ Teollisuus ja rakennustoiminta Industry and construction ........... Elinkeino tuntematon -

Industry unknown

$\begin{array}{crrrrrrr}14.3 & 11.5 & 9.4 & 7.9 & 50 & 40 & 33 & 28 \\ 7.3 & 8.4 & 9.2 & 9.9 & 25 & 29 & 32 & 34 \\ 7.2 & 9.0 & 10.0 & 10.9 & 25 & 31 & 35 & 38 \\ 0 & - & - & - & - & - & -\overline{1} & -\overline{100}\end{array}$




\section{Tammermaa}

Tammermaa

Maa- ja metsätal. sivuelinkeinoineen - Agriculture, forestry, and related

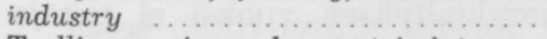
Teollisuus ja rakennustoiminta Industry and construction ........... Elinkeino tuntematon -

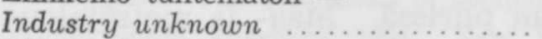

Yhteensä - Total ..............

$\begin{array}{rrrrrrrr}50.9 & 41.6 & 33.5 & 26.9 & 28 & 22 & 17 & 13 \\ & & & & & & & \\ 78.4 & 85.3 & 91.6 & 94.9 & 44 & 45 & 47 & 47 \\ 50.9 & 63.3 & 71.1 & 79.7 & 28 & 33 & 36 & 40 \\ & & & & & & & \\ 0.3 & 0.2 & 0.2 & 0.2 & 0 & 0 & 0 & 0 \\ 180.5 & 190.4 & 196.4 & 201.7 & 100 & 100 & 100 & 100\end{array}$

\section{Satakunta}

Satakunta

Maa- ja metsätal. sivuelinkeinoineen - Agriculture, forestry, and related

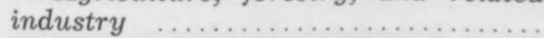

Teollisuus - Industry

$\begin{array}{rrrrrrrr}39.0 & 30.0 & 27.0 & 14.0 & 35 & 27 & 22 & 11 \\ 31.0 & 36.0 & 43.0 & 47.0 & 29 & 32 & 35 & 38 \\ 39.0 & 45.0 & 54.0 & 63.0 & 36 & 41 & 43 & 51 \\ -\overline{107.0} & \overline{111.0} & \overline{124.0} & \overline{124.0} & \overline{100} & \overline{100} & \overline{100} & -\overline{00}\end{array}$

Rakennustoiminta ja palveluelinkeinot

- Construction and service industries

Elinkeino tuntematon -

Industry unknown

Yhteensä - Total

1

\section{Kymenlaakso}

Kymenlaakso

Maa- ja metsätal. sivuelinkeinoineen - Agriculture, forestry, and related

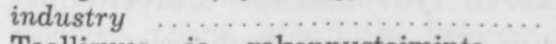
Teollisuus ja rakennustoiminta Industry and construction ........... Palveluelinkeinot - Service industries Elinkeino tuntematon -

Industry unknown

Yhteensä - Total

$\begin{array}{rrrrrrrr}21.9 & 17.4 & 12.7 & 9.6 & 26 & 19 & 13 & 10 \\ 32.7 & 35.5 & 37.7 & 39.4 & 39 & 39 & 39 & 39 \\ 29.8 & 38.0 & 45.6 & 51.9 & 35 & 42 & 48 & 51 \\ 0.1 & - & - & - & 0 & - & - & - \\ 84.5 & 90.0 & \overline{96.0} & 100.9 & 100 & 100 & 100 & 100\end{array}$

Helsingin lähivaikutusalue

Helsinki satellite region

Maa- ja metsätal. sivuelinkeinoineen -

Agriculture, forestry, and related industry

Teollisuus- ja rakennustoiminta -

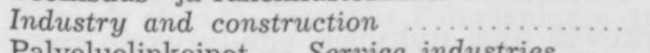

Palveluelinkeinot - Service industries .....

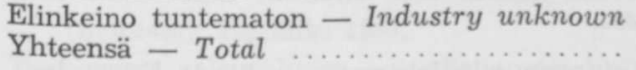

$\begin{array}{rrrrrr}9.3 & 9.0 & 7.0 & 3 & 2 & 1 \\ 136.3 & 176.9 & 210.0 & 38 & 35 & 33 \\ 210.6 & 314.1 & 423.0 & 59 & 63 & 66 \\ - & - & - & - & - & - \\ 356.2 & 500.0 & 640.0 & 100 & 100 & 100\end{array}$

elinkeinoissa toimivien lähes 40 prosenttiin. Sekä Tammermaalla että Kanta-Hämeessä ennusteen mukainen kehitys johtaa suunnilleen samanlaiseen elinkeinorakenteeseen vuonna 1990, joka Ruotsissa oli koko maassa vuonna 1960: maa- ja metsätalous $14 \%$, teollisuus- ja rakennustoiminta $45 \%$ ja palveluelinkeinot $41 \%$ (vrt. taul. 1).

Satakunnassa alkutuotannossa toimivien osuus tulee vähenemään vielä nopeammin kuin Kanta-Hämeessa. Ennusteen mukaan osuus olisi v. 1990 
vain $11 \%$ atv:sta. Teollisuusväestön lisäys olisi noin 16000 ja rakennusväestön sekä palveluelinkeinoissa toimivien noin 22000 . Koko alueen ammatissa toimiva väestö kasvaisi ennustekautena noin 17000 hengellä. Satakunnan ennusteen erilaisen elinkeinoryhmityksen vuoksi ei tietoja voida juuri verrata muihin.

Vaasan rannikkoalueen ammatissa toimivista vuonna 1960 oli melko tarkasti kolmannes kunkin elinkeinohaaran piirissä. Maa- ja metsätaloudessa toimivien määrä tulee vähenemään noin 10000 hengellä, teollisuudessa lisäys on samansuuruinen ja palveluelinkeinoissa hieman suurempi eli noin 13000 henkeä. Palveluelinkeinoissa toimivien osuus kasvaa 43 prosenttiin ja teollisuudessa toimivien osuus 40 prosenttiin.

Kymenlaakso tulee säilyttämään osan maataloudestaan, mutta teollisuuden suhteellisen osuuden ei ole ennustettu kasvavan lainkaan, joskin lukumääräisesti teollisuusväestö hieman kasvaa. Sen sijaan palveluelinkeinot saavat hyväkseen maataloudesta poissiirtyvän ja muualta tulevan työvoiman. Palveluelinkeinoissa toimivien määrä tulee kasvamaan yli puoleen kaikista ammatissa toimivista vuoteen 1990 mennessä.

Helsingin seudulla ei maatalouden osuus enää voi paljoakaan pienentyä, mutta teollisuus- ja palveluelinkeinojen suhteissa tapahtuu selvä muutos. Absoluuttisesti teollisuustyövoima lisääntyy lähes 75000 hengellä, mutta prosentuaalinen osuus vähenee kolmannekseen työvoimasta. Palveluelinkeinoissa toimivien määrä kaksinkertaistuu 35 vuoden kuluessa ja on ennusteen mukaan vuonna $20002 / 3$ kaikista ammatissa toimivista Helsingin seudulla.

Tarkastelussa mukana olleet elinkeinorakenteen alueelliset ennusteet ovat pääasiassa suuntaa antavia sekä tutkimusmenetelmien että tulostenkin kannalta. Ne antavat tietoja muutoksen kulusta, mutta irrallisina ne eivät voi muodostaa pohjaa suunnitelmalliselle yhteiskuntapolitiikalle. Ne eivät ole ennusteita siinä mielessä että ne toteutuisivat tarkkaan, vaan laskelmia kunkin alueen nyt nähtävissä olevan kehityksen perusteella. On kyseenalaista kuinka järkevää olisi nykyisin edellytyksin pyrkiä tarkkoja ennusteita laatimaankaan.

Tällaisten ennusteiden laatimista varten pitäisi ensin määritellä valtakunnallisella tasolla väestön ja tuotannon sijoittamissuunnitelma ja tavoitteet. Sen jälkeen voitaisiin yhtenäisin menetelmin laatia alueellisia ennusteita. Karkeaan kolmijakoon perustuvan elinkeinorakenteen lisäksi olisi mielekästä tutkia minkä tyyppistä teollisuutta ja minkälaisia palveluelinkeinoja kullakin alueella on sekä minkälaiset teollisuus- ja palveluammatit yleistyvät. Pelkkä elinkeinorakenteen ennuste ei ole riittävä; pitäsi selvittää myös ammattirakenteen tuleva kehitys. 


\section{Kirjallisuus}

Arpi, Gunnar. Utvecklingstendenser inom olika näringsgrenar samt befolkningsutvecklingen i rikets kommuner, tätorter och regioner. Statens offentliga utredningar (SOU) 1963: 62, 163-208. Stockholm 1963.

Befolkningen 1960-1990 I-II. Regionplansförbundet för Vasa läns kustområde (moniste). Vasa 1964, 1965.

Clark, Colin. The conditions of economic progress. London 1957.

Demographic Yearbook 1964. New York 1965.

Elinkeinot vuosina 1965-2010. Helsingin seutukaavaliitto 1967 (moniste). Helsinki 1967.

Fourastié, J. Le grand espoir du XXe siécle. Paris 1953.

Hartman, Tor. Alueellinen väestö- ja ruokakuntaennuste vuoteen 1990 saakka. Tilastollisia tiedonantoja 41. Helsinki 1964.

Kiiskinen, Auvo. Elinkeinot. Yhteiskuntatieteiden käsikirja I, 107-114. Keuruu 1963.

Laskelmia väestönkehityksestä Suomen kunnissa 1960-1990. Valtakunnansuunnittelutoimiston julkaisusarja A: 16. Helsinki 1964.

Mannermaa, Kauko. Arvio työvoiman kysynnän ja tarjonnan kehityksestä vuosina 1965-1980. Talousneuvoston sihteeristön selvityksiä, 1966, 1 (moniste). Helsinki 1966.

Palmgren, Kai. Kehittyneisyyden alueittaisista eroavuuksista Suomessa. Valtakunnansuunnittelutoimiston julkaisusarja A: 15. Helsinki 1964.

Pätäri, Ilkka. Kanta-Hämeen väestöennuste 1960-1990 seutukunnittain. Kanta-Hämeen aluesuunnitteluyhdistys (moniste). Hämeenlinna 1966.

Pätäri, Ilkka. Seutukaava-alueen väestöennuste 1966. Salon seutukaavaliitto 2-66 (moniste). Salo 1966.

Riihinen, Olavi. Alueellisen kehittyneisyyden käsitteestä ja mittaamisesta. Helsingin yliopisto. Sosiaalipolitiikan laitoksen monistesarja N:o 5. 1967.

Rostow, W. W. Taloudellisen kasvun vaiheet. Porvoo 1962.

Suomen tilastollinen vuosikirja 1940, 1948, 1950, 1960.

Suomen virallinen tilasto (SVT) VI C: 103. Yleinen väestölaskenta 1960.

Statistisk årbog 1966. Köbenhaven 1966.

Statistisk årbog 1965. Oslo 1965.

Statistisk årsbok 1945, 1955, 1965. Stockholm 1945, 1955, 1965.

Svensk ekonomi 1966-1970. Statens offentliga utredningar (SOU) 1966: 1. Stockholm 1966.

Suomela, Samuli. Salon vaikutusalueen maatalous. Salon seutukaavaliitto 6-65 (moniste). Salo 1965.

Sveriges officiella statistik: Folkräkningen 1960, IX.

Talousneuvoston mietintö lähivuosien kasvupolitiikasta. Komiteamietintö 1964: B 93 (moniste). Helsinki 1964.

Tampereen talousalueen väestöennuste 1960-1990. Tampereen seutusuunnitteluliitto (moniste). Tampere 1966.

Työvoimakatsaus 1965 ja 1956.

Väestön elinkeinojakautumat vuosina 1950 ja 1960. Valtakunnansuunnittelutoimiston julkaisusarja B: 7. Helsinki 1964.

Väestöennuste 1964, I-II. Etelä-Pohjanmaan seutukaavaliitto (moniste). Seinäjoki $1964,1965$.

$\mathrm{Ju} 1 \mathrm{k}$ aisemattomat 1 äh teet

Helsingin seutukaavaliiton laskelma Helsingin lähivaikutusalueen työpaikoista vuosina 1965,1980 ja 2000. 
Kymenlaakson seutukaavayhdistyksen laskelma väestön elinkeinorakenteesta vuosina 1970, 1980 ja 1990.

Kokemäenjokilaakson seutukaavaliiton väestöennuste 1960-1990. (Satakunnan ennustealue).

Valtakunnansuunnittelutoimiston julkaisemattomat tiedot väestön elinkeinorakenteesta vuonna 1950.

\section{Summary:}

\section{Regional Changes in the Distribution of the Population in various Industries}

\section{By KIRSTI WARTIOVAARA}

Population Research Institute

The purpose of the present article is to analyze the regional changes in the distribution of the population in various industries that have taken place during the last decades, and to present some predictions concerning expected developments in the coming decades in Finland. The data used are mostly from the official statistics and from the projected distribution of the economically active population in different industries calculated by the regional planning leagues. For the past comparisons the units of analysis are the economic regions and for future predictions the regional planning areas.

The comparison of the distribution of the population in the various industries in Finland to that of other countries between 1930-1960 (Table 1) shows that in 1960 Finland was 20-30 years behind the other countries. In all countries the proportion of the population engaged in agriculture has been decreasing, particularly in those countries where the ratio has been earlier the highest. The extent of industrialization has already come to a halt in the United States, but the proportion of service workers has been still somewhat increasing. In Scandinavia the proportion of gainfully employed out the total population has been decreasing after 1940, but the proportion of women among the economically active population has increased between 1950 and 1960 in the more advanced countries, Sweden and the United States.

The industrial structure of Finland is described according to economic regions for 1950 and 1960 (Table 2). The most industrialized zone in 1960 comprised the regions of Uusimaa, Varsinais-Suomi, Tammermaa, Southeast-Finland, Southern-Häme, and Satakunta; in other words, south and southwestern Finland. In general, less than one third of the economically active population was engaged in agriculture and forestry, somewhat more than a third in industry, and about a third in services. One exception was Uusimaa, where service workers constituted over $50 \%$ of total economically active population. A certain middle zone consisted of Central-Finland, Southern-Ostrobothnia, Northern-Ostrobothnia and the Aland Islands. Here over $40 \%$ of the economically active population was engaged in primary industries. The proportion of population engaged in industry has not increased in these regions at all, the proportion of construction workers has increased somewhat, and the proportion of the population engaged in service occupations has increased the most.

The eastern and northern regions of Finland were in the most backward position, namely, Kainuu, Central-Ostrobothnia, Lapland, Southern-Savo, Northern-Karelia 
and Northern-Savo. These are still regions dominated by agriculture. The surplus agricultural population has been somewhat absorbed by the construction industry, but the greatest increase has been on the part of the service industries, the proportion of service workers being high, e.g. because of the established public services.

Future developments in the distribution of the population in various industries have been analyzed for the whole country on the basis of two different calculations: those of Kauko Mannermaa and the so-called Vuorensyrjä calculations of the Helsinki Regional Planning League. Both of these projections take into account changes in the volume of production and gross national product, as well as the balance between the demand and supply of labor. Mannermaa's estimate of total labor force in 1980 is 3480000 persons: of these the proportion of workers in agriculture and forestry being $21 \%$, in secondary industries $35 \%$, and in service industries $44 \%$ (Table 2). Vuorensyrjä arrives at a more cautious estimate of the growth of the gross national product, and predicts 2295000 persons as the total labor force by the year 2010. According to Mannermaa's prediction, the proportion of economically active persons engaged in primary industries in 1980 will be even somewhat higher than it was in Sweden in 1960 (cf. Table 1). On the other hand, the rate of decrease in the proportion of agricultural workers depends on the demand for labor by other industries. According to Vuorensyrjä by $20107 \%$ of the labor force will be engaged in agriculture and forestry, 39 in secondary industries, and $54 \%$ in service industries.

According to predictions, after 1965 the rate of growth of the labor force will decrease. This is essentially due to the decrease in the rate of growth of the population. Factors most effecting changes in the labor force are the increased length of formal education and changes in the participation of married women and the population over 60 years of age in the labor force. In Sweden the decrease in the rate of the labor force is about as high as in Finland. In 1990 an estimated $3 \%$ of the total economically active population will be engaged in primary industries, $43 \%$ in secondary industries, and $54 \%$ in service industries.

Several regional planning leagues have done population projections that include estimated developments in the different branches of industries: Tampere economic region, Kanta-Häme, Salo regional planning areas, Southern-Ostrobothnia, and Vasa regional population projections. In addition, unpublished data are available from the Satakunta population projection for 1960-1990, information on the industrial distribution from the Kymenlaakso population projection, and calculations of the employment opportunities between $1965-2000$ in the satellite region of Helsinki.

All these projections indicate that the major factor in changes in the industrial distribution of the economically active population is the decline in the number of workers engaged in agriculture and forestry, and analyses have been concentrated on this group. Predictions in general take into consideration only the size of the arable land, the average size of the farms, and the expected developments in the relative demand for labor. The projected development is often compared e.g. to data available for similar types of regions in Sweden. On the basis of the developments in the 1950's and comparison regions predictions concerning changes have been made, where the economically active population has been calculated on the basis of the estimated demand for labor, the relationship between manpower and the demand for labor, and size of arable land. Predictions concerning the proportion of workers engaged in industry have been made on the bases of developments in the 1950's, industrial statistics and earlier research findings. The proportion of workers engaged in construction as well as that of those engaged in services is expected to depend on the growth of the industry. In addition, both the developments in the 1950's and that of the comparison regions have been taken into account. 
The predictions (Table 4) indicate that the special features of the different regions become accentuated as to their industrial structure. In 1990, most of the workers engaged in agriculture will be in the region of Salo and Southern-Ostrobothnia. The most industrialized regions will be Tammermaa, and Kanta-Häme, the coastal region of Vaasa, Kymenlaakso and Satakunta. The most service dominated region will be that of Helsinki, but also in Satakunta and Kymenlaakso over one half of the economically active population will be engaged in the service industries. With the exception of Southern-Ostrobothnia, and Salo, everywhere else the total proportion of the economically active population will increase. According to predictions, in the Helsinki region the increase will be over 200000 persons, or about $100 \%$ from 1965 to 2000; in other regions the expected increase is at best several tens of thousands.

In looking at the data it must be kept in mind that they are not predictions that will be necessarily confirmed, but only calculations based on the current situation made particularly for the purposes of physical planning. Moreover, the regional planning area predictions have been made only for the areas of specific regional planning leagues, without taking into consideration the development elsewhere. 